\title{
Devouring images: Hélio Oiticica's anthropophagic quasi-cinema
}

Article

Accepted Version

Butler, A. (2019) Devouring images: Hélio Oiticica's anthropophagic quasi-cinema. Screen, 60 (1). pp. 128-136. ISSN 1460-2474 doi: https://doi.org/10.1093/screen/hjy060 Available at https://centaur.reading.ac.uk/79494/

It is advisable to refer to the publisher's version if you intend to cite from the work. See Guidance on citing.

To link to this article DOI: http://dx.doi.org/10.1093/screen/hjy060

Publisher: Oxford University Press

All outputs in CentAUR are protected by Intellectual Property Rights law, including copyright law. Copyright and IPR is retained by the creators or other copyright holders. Terms and conditions for use of this material are defined in the End User Agreement.

\section{www.reading.ac.uk/centaur}

\section{CentAUR}

Central Archive at the University of Reading

Reading's research outputs online 
Devouring Images: Hélio Oiticica's Anthropophagic Quasi-Cinema

In the early 1970s, while living in self-imposed exile in New York, the Brazilian artist Hélio Oiticica embarked on a new phase in his artistic production, which he described as 'quasi-cinema.'1 Central to this body of work were the BlockExperiments in Cosmococa - program in progress/Blocos-Experiências em Cosmococa, installations based on slideshows devised with his compatriot, the filmmaker Neville D’Almeida. The title 'Cosmococa', combining cosmos and cocaine, refers to Oiticica's interest in 'organized delirium', as the poet Haroldo de Campos put it, and his preferred recreational means for achieving this. Culturally, cocaine linked the indigenous traditions of South America with the marginal sub-cultures of the modern city; in the early 1970s, with Nixon's war on drugs just beginning, it was also relatively cheap and had not yet become either the yuppie drug of choice or the focus of organized crime; its health risks were also not yet well understood. ${ }^{2}$ In the installations, cocaine is used as a drawing medium, to make 'lines' on images appropriated from Oiticica's new surroundings: record sleeves and book covers bearing the faces or names of Jimi Hendrix, Marilyn Monroe, John Cage and Yoko Ono, key figures in the media culture of the national context to which the two Brazilians had relocated. Oiticica describes this use of unoriginal images as 'DUCHAMPIAN sarcasm.' More liminal than counter-cultural, the Cosmococas were devised in secret and not shown in public until 1992, twelve years after Oiticica's untimely death. ${ }^{4}$ As interest in Oiticica has grown, they have been incorporated into the repertoire of contemporary art museums, appearing with increasing frequency as part of solo retrospectives and group shows. Their presentation in these contexts as 
'expanded cinema' belies their complex marginality and their historical significance as intermedial works shaped by a distinctively Brazilian cultural logic that responds to the experience of exile, to encounters with the New York avant-garde and underground scenes, and to the cultural power of American mass media.

Nine installations were planned in the series, and developed to varying degrees. Five were collaborations with Neville D’Almeida, completed in 1973. CC1 Trashiscapes consists of three slide series played on two projectors, with a soundtrack of Brazilian folk music, Jimi Hendrix, Stockhausen and street sounds. Participants were expected to lounge on mattresses and file their nails while surrounded by imagery including the cover of Frank Zappa's album Weasels Ripped My Flesh, decorated with drawings made from lines of cocaine. A slide showing cocaine being cut on Buñuel's eye puns on Un Chien andalou, invoking a cinema of discontinuity, but also signalling a break from avant-garde film tradition. The title of $C C 2$ Onobject refers to Yoko Ono, but also to Ferreira Gullar's influential neoconcretist manifesto 'Theory of the Non-object'. 5 The slides show the cover Grapefruit, Ono's 1964 book of instructions for art performances and several other books, with cocaine drawings on them. The soundtrack combines Ono's experimental music with other sounds. CC3 Maileryn, with a title that splices together the names 'Marilyn' and 'Mailer', uses images from Norman Mailer's biography of Marilyn Monroe on five slide projectors, in an environment with sand, white vinyl and balloons. CC4 Nocagions takes place in a swimming pool surrounded by lounging mats, and features images of John Cage's book Notations (1969) with cocaine on the cover, projected on two opposite walls and soundtrack based on one of Cage's compositions. The 
diagonal orientation of the projection makes reference to Malevich's White on White (1918), an art-historical pun on white cocaine on a white book cover. CC5 Hendrix-War has five slide projectors, ten cocoon-like hammocks suspended across the space, and a soundtrack including music by Hendrix. The numbering and the sub-title 'program in progress' imply a modular, open-ended series to which more could be added. Oiticica's notes also specify differences in presentation for public and private showings, with the former taking the shape of exhibitions or happenings and the latter more like private house parties, of potentially quite long duration and flexible arrangements to allow for creative participation. ${ }^{6}$

The Cosmococas occupy a problematic place in Oiticica's work as a whole. Luis Camnitzer writes dismissively that after moving to New York, Oiticica continued his previous projects, and 'Inspired by the disco and drug scene [...] worked on his less satisfactory slide-show environments. ${ }^{7}$ Irene Small has written several articles about them, but excludes them from her important monograph, Hélio Oiticica: Folding the Frame, although they would seem to fit perfectly into the trajectory she maps for Oiticica's work as a progressive complication of the spatial relations between the inside and the outside of art works and artistic practice. ${ }^{8}$ A key characteristic of the work of Oiticica and his neoconcretist and post-neoconcretist contemporaries is the development of experiential and environmental forms designed for spectator participation artworks made for a viewer to move around or handle. As in Rosalind Krauss's definition of the expanded field, this involves a rotation out of the vertical plane of traditional art objects and into the horizontal field of an event or a 
relationship, which the artists conceptualised in phenomenological terms. ${ }^{9}$ In Brazil, this was encapsulated in Ferreira Gullar's theory of the 'non-object':

The spectator is solicited to use the 'non-object'... mere contemplation is not enough to reveal the sense of the work... the spectator goes from contemplation to action... what his action produces is the work itself, because that use, foreseen in the structure of the work, is absorbed by it, revealed and incorporated into its signification. ${ }^{10}$

Oiticica's movement into the space around the artwork and into a physical and social engagement with viewers was extended through the use of structures he called 'penetrables', and through tents and nests. These forms were scaled to the human body, and to social interactions, some for one or two people, some for a whole group. His engagement with the physical experience of space culminated in the creation of the parangolés, pieces of fabric made of various materials from silk to sacking or plastic, to be used as a cape, a banner, a standard, or a tent, and intended to be seen in motion, preferably dancing. In a notorious episode in 1965, he invited friends from Mangueira, a favela in Rio de Janeiro, to perform with the parangolés in a procession at the opening of his show at the Museum of Modern Art in Rio de Janeiro. When the museum director refused to allow the group to enter the building, the performance was premiered in the park outside. $^{11}$

As well as extending spatially, Oiticica's practice from the late 1950s to the early 1970s extends socially, culturally, and intermedially, moving from clean-cut minimalism to complicated entanglements with popular culture, music, dance, television and film, drugs, and marginal subcultures, from neoconcretism to Tropicália to 'tropicamp' (as Oiticica termed his queer aesthetic of resistance). 
From the mid-1960s onwards, his engagement with the marginal is a political response to the dictatorship. His quasi-cinemas can be seen as the culmination of this formal expansion and an attempt to locate resistance in a new context, during his sojourn in New York.

Art historians routinely refer to the Cosmococas as 'expanded cinema', but this categorization suppresses some crucial and critical aspects of Oiticica's conception of 'quasi-cinema', which means 'almost cinema' or 'resembling cinema' or even 'virtual cinema'. Like the fold which is the central epistemological figure in Irene Small's study of Oiticica, 'quasi' names a relationship of sameness and difference. Oiticica arrived in New York City in 1970, five years after Jonas Mekas's Expanded Cinema Festival, held at the FilmMakers' Cinemathèque, and in the year of the publication of Gene Youngblood's influential book Expanded Cinema, which defined its object as follows:

When we say expanded cinema we actually mean expanded consciousness. Expanded cinema does not mean computer films, video phosphors, atomic light, or spherical projections. Expanded cinema isn't a movie at all: like life it's a process of becoming, man's ongoing historical drive to manifest his consciousness outside of his mind, in front of his eyes. One no longer can specialize in a single discipline and hope truthfully to express a clear picture of its relationships in the environment. This is especially true in the case of the intermedia network of cinema and television, which now functions as nothing less than the nervous system of mankind. ${ }^{12}$ Along with the Vortex concerts and the multi-channel experiments of Stan Vanderbeek, Youngblood includes an eclectic range of films, from Brakhage's abstract film poems to Kubrick's 2001, most of them actually works for single 
screen cinema exhibition. The book was written too soon to include many important works from the 1970s. Its vision is narrowly North American, and in many respects it reads like The Whole Earth Catalog for films. More recently, and in the light of another 40 years of film history, A. L. Rees has surveyed the field of expanded cinema practices, noting the wide range of usages of the term and practices encompassed. He divides the 'overall vision' of expanded cinema into three projects:

The first was to melt down all art forms, including film, into multimedia and live-action events. The second was to explore electronic technologies and the coming of cyberspace, as heralded by Marshall McLuhan. The third was to break down the barrier between artist and audience through new kinds of participation. Each of these challenged existing notions of cinema as a commercialised regime of passive consumption and entertainment. ${ }^{13}$ Oiticica shared some of Youngblood's cultural references and enthusiasms McLuhan's media theory, psychosexual desublimation, multisensory experience ${ }^{14}$ - but he didn't share Youngblood's naïve enthusiasm for the emerging technoculture. Youngblood framed his understanding of expanded cinema in evolutionary terms, as a synaesthesic response to the information-rich environment of the cybernetic age and a purification of film form - using the term 'pure cinema' quite frequently. For Oiticica, famously, purity is a myth - and not a particularly enabling one. ${ }^{15}$ Nor do the Cosmococas fit neatly into any of Rees's three categories - mediums are not merged in the installations, but fragmented; the approach is decidedly low-tech; the participatory project Rees describes is a better fit, but doesn't capture the extent to which authorship is 
thrown into question by the use of appropriated materials and the performative contribution made by participants in the work.

In fact, although Oiticica was inspired to create 'quasi-cinemas' by the slideshows of performance artist and filmmaker Jack Smith, ${ }^{16}$ and liked the aesthetic of Warhol and Morrissey's work, if not its commercial orientation, he did not fit comfortably into the experimental film scene. In a letter written in 1971 he describes Anthology Film Archives as 'a horrible place' where the famous seating designed by Peter Kubelka made him feel lonely and bored. ${ }^{17}$ The key term in his thinking about film and media is 'fragmentation' which he found in Jack Smith's slide-shows and Neville D’Almeida's films, which he described as exploding into 'moment-frames'. Significantly, given the use of found images in the Cosmococas, he was impressed by D'Almeida's use of posters in the film Garden of War (Jardim de guerra 1968) 'as a kind of film language.' He also admired Godard's films from the late 60s and early 70s for their disjunctive aesthetics, which he described as 'joyful [...] liberation of the spectator from the tyranny of image and language.'18 His venture into 'quasi-cinema' came not from an interest in film's immersive potential, but from dissatisfaction with the passivity it seemed to induce in the spectator:

(N)ot to be contented by the relationship (mainly the visual one) of spectator-spectacle (nurtured by cinema-disintegrated by teevee) and the wide-spread indifference of such notions: the prevalent blindfaith acceptance of that relationship's immutability the spectator's hypnosis and submission to the screen's visual and absolute super-definition always seemed to me too prolonged the pictures changed but somehow remained the same: why? ${ }^{19}$ 
The aim of quasi-cinema is to break this flow in order to 'negate the unilateral character of cinema-spectacle.'20 Instead of using moving images that immobilize the spectator, Oiticica and D'Almeida use still images that are set in motion by the viewer's gaze and body. As Irene Small notes: 'In the Cosmococas, cinema is reconstituted as a temporal container for bodily action in which the representational status of the projected image is shared with the bodies of its participants.'21 The absence of a point of view structure or narrative leaves spectator-participants free to explore the space in their own time. The principle of fragmentation also applies to the titles, with their cut and spliced wordplay. Fragmentation is the major formal principle in the Cosmococas, with the intention of creating a space for active participation of a kind not normally associated with cinema.

Oiticica is a rare example of an artist who has worked across the expanded field in the visual arts, in a way that might satisfy Rosalind Krauss's rigorous definition, and expanded cinema, as fuzzily expounded by Jonas Mekas and Gene Youngblood. Andrew Uroskie has excavated the connection - and disconnection - between these two clearly historically linked cultural phenomena:

For art critics of Krauss's generation, engaged in an arduous struggle to shift profoundly conservative institutions of art and academe toward an engagement with the deeply suspect terrain of contemporary art and Continental philosophy, Youngblood's subject matter alone made the book a difficult sell; the rhetorical style consigned it to oblivion. As the principal optic through which the idea of expanded cinema would be viewed, Youngblood's book ironically ensured that the idea was largely excised from the art historical record. ${ }^{22}$ 
The inclusion of works from the Cosmococa series in shows such as Walker Art's ‘Hippie Modernism’ (2015) and Gallerie Lelong’s ‘Organized Delirium - New York 1970-1978' (2005) suggests that the installations might occupy the terrain between Krauss's high theory and Youngblood's cosmic rhetoric, although the positioning of Oiticica's quasi-cinema alongside works by artists including Gordon Matta-Clark and Robert Smithson draws attention to their differences as well as their similarities. The comparison with Robert Smithson is especially suggestive - both artists brought materials such as earth and sand into the gallery as a way of setting up a topological dialectic between inside and outside, or as Smithson termed it, site and non-site. Both were fascinated with structures and materials that could generate spatial and temporal complexity, including labyrinths and mirrors, as well as film. Both were prolific writers in a particular trippy-theoretical mode (and Oiticica's 'quasi-cinema' echoes Smithson's 'quasiinfinities'). In a perspicacious reading of Oiticica's artistic development 'from plane to space', Guilherme Teixeira Wisnik argues that there are crucial differences between the work of Oiticica and his Brazilian contemporaries and the North American minimalists who staked out the expanded field, determined by the nature of public space available to the artists. In the USA, Wisnik suggests, placing artworks in public space (i.e. as public art) confers value on them, or provokes debate about their value, assuming a relatively stable context for this to take place. In Brazil, not only because of the dictatorship, but also because of the particular legacy of colonialism and slavery and the manner of urban development, public space has a more precarious existence. Comparing the construction of American works of Land Art in the desert with the construction of Brasilia on a depopulated plateau, Wisnik remarks that one represents a 
radical flight from institutionalization, while the other entails the exile of the state itself 'spelling out and consecrating the eternal absence of the public dimension in Brazil' (my translation). ${ }^{23}$ From this arises the central paradox of Oiticica's art, as noted by Nuno Ramos, that the materialization of the work in the world ends up creating a refuge within it. ${ }^{24}$ Both the expanded field and expanded cinema rely on a strong conception of public space, into which the consciousness of the individual artist can be projected. For Brazilians of Oiticica's generation this was not something to be taken for granted (nor was it possible in the USA, given his marginal status as a drug-dealing immigrant without a visa). Instead, Oiticica created participatory spaces of subjectivation, on the boundary between public and private life.

Intermediality is a defining feature of this approach, as it is the gaps between mediums that create the space for participation. As an avant-garde artistic practice, 'intermedia' was defined by Fluxus artist Dick Higgins in 1966. ${ }^{25}$ Taking the happening as an example, Higgins defines 'an intermedium' as 'an uncharted land that lies between collage, music and the theater.'26 Without elaboration, Higgins throws in a tantalizing suggestion that negation and differentiation might have a defining role to play in intermediality: 'The concept itself is better understood by what it is not, rather than what it is.'27 This is consonant with the prevailing model for dealing with alterity in the Brazilian avant-garde, the idea of anthropophagy, or cultural cannibalism, introduced by Oswald de Andrade in 1928 and revived by the Tropicalist movement of the 1960s. Where intermediality in some contexts might signify a harmonious fusion, an anthropophagic model of intermediality is more political: one medium 
devours another and assumes its qualities as a means of overcoming it. As Christopher T. Funkhouser explains:

The anthropophagic aesthetic of mechanically consuming a text to give birth to a new text suggests a type of shifting, combined realization. External material is consumed, digested, and restated as an altered entity. Historically, this process of absorbing pertinent foreign matter has been a technique used to combat and transcend colonialism. Beyond that objective, it instils cultural relevance by promoting the value of diversity and discrepancy in multiple registers. ${ }^{28}$

The political dimension of anthropophagy is similarly foregrounded in this remark by Caetano Veloso: 'The idea of cultural cannibalism fit us tropicalists like a glove. We were "eating" the Beatles and Jimi Hendrix. Our arguments against the defensive attitudes of the nationalists found here a succinct and exhaustive formulation.'29 In Brazilian cultural politics of the 1960s, anthropophagy was associated with a progressive transnationalism (although globalized commercialism has subsequently given rise to a regressive version, which Suely Rolnik terms 'zombie anthropophagy'30). After the authoritarian dictatorship sent many artists into exile, anthropophagy and intermediality became associated with displaced articulations of identity, as Samuel Paiva explains:

[I]ntermediality as a concept [...] seems fundamental in methodological terms, for a mapping of tropicalist production, including that aspect that has not yet been discussed and which concerns exile, as a place of displacement in relation to the country left behind, but also as a place for 
closer encounter and interaction with the exiles confronted with the possibility of a radically displaced national identity. (My translation). ${ }^{31}$ Oiticica's quasi-cinema was a way of engaging with the powerful media of the host nation he found himself in. Fragmented cinematic forms and cocainecovered icons cleared a habitable space for the embodied performance of a displaced subjectivity.

Anthropophagic intermediality provides a context for understanding the content as well as the form of the Cosmococas. While artists including Yoko Ono and John Cage are clearly referenced as role models, the meanings of the figures of Jimi Hendrix and Marilyn Monroe in the installations are less clear. In an essay exploring the significance of Hendrix in Oiticica's art and writing, Sérgio B. Martins makes a persuasive case for the interpretation of the dead rock star in Oiticica's personal mythology as a Nietzschean tragic hero and the central figure, in CC5 Hendrix-War, of a Dionysian ritual. Thus, 'Hendrix's face on the cover of War Heroes, clad in an intoxicating and ever-changing mask [of lines of cocaine], is the face of a "warrior hero" whose sacrifice brings about [...] collective transformation'. Martins concludes that CC5 Hendrix-War is a 'poignant, albeit affirmative work of mourning.'32 Oiticica's involvement in the Brazilian music scene is well-known; in exile, he became an ardent admirer of British and North American rock stars, including Hendrix, the Rolling Stones and Alice Cooper. But besides the transformative potential of the music, he seems also to have been fascinated - and horrified - by the condition of stardom. In a letter to fellow artist Lygia Clark, written in 1968, he imagines the spectator of artworks as consuming the artist: 'I devour you and then I shit you out.'33 Both artists were close friends of Caetano Veloso at the height of his fame, and Oiticica describes 
how Veloso 'is totally devoured, in an almost physical sense,' by his fans, 'a poet, ultra-sensitive, [...] thrown into an arena of wild beasts.' Relating the famous incident in which Veloso and Os Mutantes were booed at the Third International Festival of Popular Song in 1967, Oiticica writes of 'the disjunction between the always noble, etc., intentions of the artist and the fury of the participatory relation.' 34

The notion of mass media as devouring is also evident in Oiticica's attitude to moving images. His comments on the effects of the television monitor in one of the penetrables in the Tropicália installation suggest that he felt threatened by the medium:

When you sit down on the stool in the inside the television images come out as if they were sitting on your lap ... The terrible feeling I had inside was of being devoured by the work. ${ }^{35}$

Oiticica's remarks evoke anthropophagy, not in its positive, anti-colonial sense, but as a metaphor for cultural domination. As Christopher Dunn points out, the notion of cultural anthropophagy is 'a complex and multivalent trope with both destructive and regenerative implications.' ${ }^{36}$ Oiticica elaborated on his understanding of 'the problem of the image' in an essay on the Tropicália installation: 'It is the image which then devours the participant, because it is more active than his sensorial activity.' ${ }^{37}$ As Dunn glosses this passage: 'Oiticica referenced Oswald de Andrade’s anthropophagy not as a triumphant, anticolonial devouring of metropolitan culture and power, but rather as a mechanism of domination and erasure.'38

In the Cosmococas, cinema, a medium composed of other mediums, is broken down to its constituent elements, so that instead of devouring or 
overwhelming the spectator, it invites - indeed requires - active engagement. The iconic faces of stars devoured by mass media are transfigured by cocaine, and freed from both the star system and the 'verbi-voco-visual strait-jacket'39 of linear narrative film form. Quasi-cinema is an anthropophagic defence against being consumed by dominant media.

The intermediality of the Cosmococas also subtends their collaborative nature: in the written descriptions, or 'propositions' for the first five installations, Oiticica engages enthusiastically with Neville D’Almeida's work as a filmmaker, and the remaining four propositions are essentially invitations to collaborate made to Guy Brett, Thomas Valentin and others. The iconic figures whose faces and names are given such prominence in the installations, including Hendrix and Monroe, might also be counted as collaborators. While Oiticica's meticulous instructions for the installations place great emphasis on his authorship of the 'propositions' and the importance of his writing about the project, the contributions of others, in other mediums, are generously credited and the involvement of participants is essential to their realisation. As Vito Aconcci has pointed out, the work that Oiticica made in New York pioneered a new form of sociality in art: '[H]e had a very interesting notion of public space, that it's not just for large groups of people, it's a composite of private spaces [...] His work seemed so much about relations between people - before mine was.' ${ }^{40}$ Recent presentations of the Cosmococas stress this sociality, positioning the installations as archival relics of radical scenes of the '70s and antecedents of contemporary relational aesthetics, but the conflict between genuinely participatory practices and gallery decorum that Oiticica's work aggravated in his lifetime remains, as one reviewer of the recent retrospective in Chicago 
notes: 'One could unwind [in the installations] - until the rebukes of the guards, directed at anyone who stepped so much as a foot away from the room in stockinged feet, demarcated where this paradise ended.' ${ }^{41}$ Moreover, in situations where this conflict appears to have been resolved, such as the sculpture park at Inhotim, in Minas Gerais, Brazil, where the first five Cosmococas are permanently installed and have become popular tourist attractions, it is at the cost of glossing over challenging aspects of the work - its queer sociality, its enthusiastic endorsement of drug-taking - while also failing to address the underlying question of mediated social relations in public space, an issue that has only intensified since the works' conception. ${ }^{42}$ While it might not be possible to exhibit the Cosmococas today without assimilating them to a conformist art history that positions them either as precursors of immersive video installation or counter-cultural throwbacks, understanding them through the critical perspective of anthropophagic intermediality allows for the recognition of diversity within the broad category of expanded cinema, and reveals the political potential still contained with them.

\footnotetext{
${ }^{1}$ Oiticica's interest in cinema also led to appearances in films by Glauber Rocha, Neville D'Almeida, Julio Bressane and Ivan Cardoso and to the making of several of his own super 8 films, including Agrippina é Roma Manhattan (1972). 2 See Max Jorge Hinderer Cruz, 'Hélio's COUSIN', in Stefan Solomon (ed.), Tropicália and Beyond: Dialogues in Brazilian Film History (Berlin: Archive Books and University of Reading, 2017), pp. 231-239.

${ }^{3}$ Hélio Oiticica, 'Block-Experiments in Cosmococa - Program in Progress', in Carlos Basualdo (ed.), Hélio Oiticica: Quasi Cinemas (Ostfildern: Hatje Cantz, 2002), p99.

${ }^{4}$ Oiticica's close friend Waly Salomão recounts having been shown the work under conditions of strictest secrecy; see Sabeth Buchmann and Max Jorge Hinderer Cruz, Hélio Oiticica and Neville D'Almeida: Block-Experiments in Cosmococa - Program in Progress, (Afterall: London, 2013), p3ff.

${ }^{5}$ See Michael Asbury, 'Neoconcretism and Minimalism: On Ferreira Gullar's Theory of the Non-Object', in K. Mercer, ed., Cosmopolitan Modernism (Iniva/MIT, London and Cambridge, MA: 2005), pp168-189.
} 
${ }^{6}$ Oiticica wrote detailed notes on how many copies should be made, how they should be presented, including the number and positioning of slide projectors, timings and the use of props.

${ }^{7}$ Luis Camnitzer, Conceptualism in Latin American Art: Didactics of Liberation (Austin, University of Texas Press: 2007), p230.

8 Irene V. Small, Hélio Oiticica: Folding the Frame (Chicago: University of Chicago Press, 2016). See also Irene V. Small, 'One Thing After Another: How We Spend Time in Hélio Oiticica's Quasi-Cinemas', Spectator: USC Journal of Film and Television Criticism, 28/2 (Fall 2008), pp73-89, and 'Toward a Deliterate Cinema: Hélio Oiticica and Neville D'Almeida's Block-Experiences in Cosmococa Program in Progress (1973)', in Elizabeth Carpenter (ed), On Performativity, vol. 1, Livings Collections Catalogue, (Minneapolis: Walker Art Center, 2014), online at: http://walkerart.org/collections/publications/performativity/deliteratecinema/accessed 4 February 2018.

${ }^{9}$ Rosalind Krauss, 'Sculpture in the Expanded Field', October, vol. 8, 1979, pp3144.

10 Ferreira Gullar, 'Diálogo sobre o não-objeto' (1960), cited in Monica Amor, 'From Work to Frame, In Between, and Beyond: Lygia Clark and Hélio Oiticica, 1959-1964', Grey Room, 38, Winter 2010, pp20-37.

11 Three decades later, in 1994, a similar group was ejected from the Sao Paulo Biennial, indicating how long it is taking the art world to come to terms with the social and performative qualities of Oiticica's work.

12 Gene Youngblood, Expanded Cinema (New York: P. Dutton \& Co, 1970), p41.

13 A. L. Rees, 'Expanded Cinema and Narrative: A Troubled History', in Rees et al (eds), Expanded Cinema: Art Performance Film (London: Tate 2011), p13.

14 Conceptualized by Youngblood as synesthesia and by Oiticica as the suprasensory.

15 The words 'Pureza é um mito' are inscribed on one of the penetrables in the Tropicália installation.

16 Specifically, Travelogue to Atlantis, shown in Smith's loft in 1971. For a fascinating comparison of Smith and Oiticica's tropical engagements, see Juan A. Suárez, 'Jack Smith, Hélio Oiticica, Tropicalism', Criticism, 56/2, (Spring 2014), pp295-328.

17 Letter addressed to Ivan Cardoso and other friends on February 23, 1971; cited in Small, 'Toward a Deliterate Cinema: Hélio Oiticica and Neville D'Almeida's Block-Experiences in Cosmococa - Program in Progress (1973)'. ${ }^{18}$ Hélio Oiticica, 'Block-Experiments in Cosmococa - Program in Progress', p98. 19 Ibid, p97.

20 Ibid, p98.

${ }^{21}$ Irene V. Small, 'Toward a Deliterate Cinema'.

22 Andrew V. Uroskie, Between the Black Box and the White Cube: Expanded Cinema and Postwar Art (Chicago: University of Chicago, 2014), p10.

${ }^{23}$ Guilherme Teixeira Wisnik, 'Dentro do labirinto: Hélio Oiticica e o desafio do "público" no Brasil', ARS (São Paulo), vol.15, n.30, 2017, pp95-110.

http://www.scielo.br/pdf/ars/v15n30/2178-0447-ars-15-30-00095.pdf accessed 4 February 2018.

24 Ibid. 
25 Dick Higgins, 'Intermedia', The Something Else Press Newsletter, vol. 1, no. 1, February 1966, pp1-3.

${ }^{26}$ Ibid, p3.

27 Ibid.

${ }^{28}$ Christopher T. Funkhouser, New Directions in Digital Poetry (London: Continuum, 2012), p230.

${ }^{29}$ Dunn, 'Mapping Tropicália', in T.S. Brown and A. Lison (eds), The Global Sixties in Sound and Vision (New York: Palgrave Macmillan, 2014), p34.

30 Suely Rolnik, 'Avoiding False Problems: Politics of the Fluid, Hybrid, and Flexible', e-flux journal, No. 25, May 2011. http://www.e-

flux.com/journal/25/67892/avoiding-false-problems-politics-of-the-fluidhybrid-and-flexible/ accessed 4 February 2018.

31 The original reads: '[I]ntermidialidade como um conceito [...] parece fundamental, em termos metodológicos, para um mapeamento da produção tropicalista, inclusive dessa vertente ainda pouco discutida e que diz respeito ao exílio, como um lugar de deslocamento em relação ao país deixado para trás, mas também como espaço de encontro e interação mais próxima dos exilados confrontados com a possibilidade de uma identidade nacional radicalmente deslocada.' Samuel Paiva, 'Um Aspecto da Tropicália: a Intermidialidade como Resposta ao Exílio', Rumores, vol. 10, no. 19, pp105-120, July 2016.

https://www.revistas.usp.br/Rumores/article/view/112364 accessed 4 February 2018.

32 Sérgio B. Martins, 'Hendrix Unbound: Hélio Oiticica's Tragic Take on Rock', in Lynn Zelevansky (ed.), Hélio Oiticica: to Organize Delirium (Munich, London and New York: Del Monico Books, Prestel, 2016), pp221.

${ }^{33}$ Claire Bishop, Participation (London: Whitechapel Gallery, 2006), p111.

34 Ibid, p112.

35 Hélio Oiticica, Hélio Oiticica: 25 February-6 April 1969, Whitechapel Gallery, cited in Irene V. Small, Hélio Oiticica: Folding the Frame, p262.

${ }^{36}$ Christopher Dunn, op cit, p32.

37 Hélio Oiticica, 'Tropicália', cited in Christopher Dunn, Contracultura:

Alternative Arts and Social Transformation in Authoritarian Brazil (Chapel Hill: University of North Carolina Press, 2016), p79.

38 Ibid.

${ }^{39}$ Hélio Oiticica, 'Block-Experiments in Cosmococa - Program in Progress', p100. 40 Vito Aconcci, interviewed in the video Héliophonia (Marcos Bonisson, 2002), http://www.marcosbonisson.com/Heliophonia accessed 4 February 2018. ${ }^{41}$ Lauren DeLand, 'Hélio Oiticica at the Art Institute of Chicago', Art in America, May 26, 2017. http://www.artinamericamagazine.com/reviews/hlio-oiticica/ accessed 4 February 2018.

42 See Maria Angélica Melendi, 'Legal no ilegal: as Cosmococas, a Subterrânia e os jardins do Museu', ARS (São Paulo), vol.15, n.30, 2017, pp.149-160.

http://www.scielo.br/pdf/ars/v15n30/2178-0447-ars-15-30-00149.pdf accessed 4 February 2018. 